\title{
LUT
}

University

\section{Regional material flow tools to promote circular economy}

Virtanen Maarit, Manskinen Kati, Uusitalo Ville, Syvänne Jenni, Cura Kirsti

This is a Post-print version of a publication

published by Elsevier

in Journal of Cleaner Production

DOI: $\quad 10.1016 /$ j.jclepro.2019.06.326

Copyright of the original publication: (c) 2019 Elsevier Ltd.

Please cite the publication as follows:

Virtanen, M., Manskinen, K., Uusitalo, V., Syvänne, J., Cura, K. 2019. Regional material flow tools to promote circular economy. Journal of Cleaner Production, 2019, 235, 1020-1025. https:// doi.org/10.1016/j.jclepro.2019.06.326

This is a parallel published version of an original publication.

This version can differ from the original published article. 


\title{
Regional material flow tools to promote circular economy
}

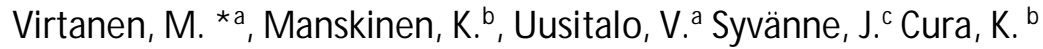 \\ a Lappeenranta-Lahti University of Technology, School of Energy Systems, Sustainability Science. \\ Saimaankatu 11, 15140 Lahti \\ b Lahti University of Applied Sciences, Faculty of Technology, Niemenkatu 73; 15140 Lahti, Finland \\ ' M uovipoli Ltd., Niemenkatu 73; 15140 Lahti, Finland \\ * Corresponding Author. Current address: Lappeenranta-Lahti University of Technology, School of \\ Energy Systems, Sustainability Science. Saimaankatu 11, 15140 Lahti, Finland. Tel.: +358 40530 \\ 7258; E-mail: maarit.virtanen@student.lut.fi
}

\begin{abstract}
Although the concept of circular economy is gaining increasing attention, there is a lack of tools or any agreed methodology for evaluating circularity. To date, circularity has been assessed mainly at product level, but national and regional level assessment is also essential in evaluating the effectiveness of circular economy strategies. As regions play an important role in implementing both EU and national strategies, the paper seeks to develop indicators for evaluating the circularity of material flows at regional level. In the case region of Päijät-Häme in Finland, the circular economy strategy is among the region's smart specialisation spearheads, and Päijät-Häme has a road map for moving towards a circular economy. The material flows examined in this study were phosphorous, plastics, textiles, waste wood and ash. While the region has high utilisation rates for plastics, textiles and waste wood, a significant proportion of material flows relates to energy production rather than material recycling. The present analysis highlights the difficulty of obtaining regional-level information on material flows; the available information and statistics relate mainly to waste flows or to national averages that do not necessarily reflect regional characteristics. For that reason, the indicators are based on circulation of waste materials rather than material circulation for the whole value chain from manufacturing to reuse and recycling. Nevertheless, the developed indicators provide a simple measure of circularity for regional material flows and can be further developed as more information becomes available.
\end{abstract}

Keywords: circular economy, regional approach, waste flows, energy use, material use

\section{INTRODUCTION}

As a consequence of human activities, environmental challenges such as climate change, biodiversity loss and flows of nitrogen $(\mathrm{N})$ and phosphorus $(\mathrm{P})$ now exceed safe or sustainable limits limits as first presented by Rockström et al. (2009) and then updated by Steffen et al. (2015). These challenges are linked to material and energy consumption, which are expected to continue to grow as a result of increasing global population and gross domestic production in the decades ahead (Dittrich et al., 2012). According to Lettenmeier et al. (2014), a sustainable annual level of global material consumption would be 8 t per capita. However, Bringezu et al. (2009) reported that, in industrialized countries, annual material consumption per capita is $40-50 \mathrm{t}$. 
Circular economy (CE) thinking is seen as a possible solution to these problems. By moving from a linear economy to one based on closed loops of material flows, CE aims to optimise the utility and value of materials, products and components. This circularity of materials and associated new services should also create new business (Ellen MacArthur Foundation, 2015). However, although the concept is widely used, there is no agreed scientific definition of CE. In their analysis, Kirchherr et al. (2017) defined CE as an economic system based on business models that eliminate the 'end-oflife' concept by reducing, reusing, recycling and recovering materials in production, distribution and consumption contexts at micro, meso and macro level, with sustainable development as the goal.

In the existing literature, use of the CE concept in relation to material flows commonly fails to address the waste hierarchy while continuing to emphasise recycling (Korhonen et al., 2018). Properly used, however, CE is based on the $4 \mathrm{R}$ framework of reduce, reuse, recycle and recover (European Commission, 2008) to ensure sustainable use of materials and energy. As Korhonen et al. (2018) noted, CE processes of reuse, remanufacturing, refurbishment and recycling will ultimately lead to unsustainable levels of resource depletion and pollution unless the growth in physical scale of the economic system is checked. Additionally, combustion for energy and recycling for raw material value only should be avoided wherever possible.

According to Witjes and Lozano (2016), one of the key issues for new models of CE is to improve collaboration between producers and suppliers. Cooperation is vital because CE sideflows from one process can be used as feedstock for other processes, creating linkages between them. Di M aio et al. (2017) suggested that, in addition to previous mass-based measurements, resource efficiency and CE should be measured in terms of the market value of stressed resources. As another indicator for evaluating CE, Huysman et al. (2017) included quality of material flow and environmental benefits. Based on a case study of waste plastic, they showed that this kind of indicator can help to facilitate decision making. Another example of circularity indicators is the longevity indicator presented by Franklin-Johnson et al. (2016), which measures the material retention based on the amount of time a resource is kept in use. This is vital information for $C E$, but however first requires a Life Cycle Analysis (LCA) for the product and its components studied. According to ScoreLCA (2015), consequential LCA could be a solution for studying circularity and the impact of changes made during the life cycle, but the evaluation process requires a considerable amount of data and knowledge.

In addition to individual indicators, Saidani et al. (2018) provide a taxonomy of circularity indicators based on the analysis of both academic and grey literature. The authors classified altogether 55 indicators in 10 categories based on, for instance, the level of implementation (micro, meso, macro), the CE loops (maintain, reuse, remanufacture, recycle) and the perspective of circularity (actual, potential). The study indicates that CE indicators already exist, but there is still a lack of holistic indicators and knowledge on the usability of different types of indicators.

Circularity has also been assessed in a global level. In a material flow analysis of the circularity of the global economy, Haas et al. (2016) estimated that about $7 \%$ of material input flows are closed while $30 \%$ are net additions to so cioeconomic stock. The analysis determined whether a specific material was used for energy production or as raw material for other processes, and whether materials were used within one year or remained as socioeconomic stock.

Although several previous studies have attempted to measure CE or to create relevant indicators, there is still a knowledge deficit in relation to regional indicators. Regions play an important role in 
implementing EU and national policies, but there is currently no uniform methodology to compare their degree of movement towards CE (Smol et al., 2017). As the lack of indicators makes it more difficult to set and pursue regional targets, the aim of this study was to develop a tool to evaluate the circularity of various waste material flows at regional level. Based on real data, we can also determine which materials are best studied at regional level and which require a global perspective. Finally, the study sought to identify factors that impact the circularity of different materials.

\section{MATERIALS AND METHODS}

For the purposes of this research, the current state of CE for selected waste material flows was modelled at a regional level. The case region, Päijät-Häme in Southern Finland, is characterised by small and medium-sized enterprises within a diverse economy. Traditional process industries including forestry, furniture, and metal, plastic and textile goods play a significant role in the region. However, structural change has impacted these traditional industries, and in pursuing new business growth, CE is one of the region's key smart specialisations (Regional Council of Päijät-Häme, 2017).

Among the various material flows in Päijät-Häme, seven were included in the study: phosphorus, nitrogen, plastics, textiles, waste wood, ash and metals. Of these, five were selected for detailed analysis. The selected materials differ in their qualities and volumes of flow. In developing material flow indicators, the information collected included material inputs to the region, production in the region and circulation of materials through recycling, energy recovery and disposal as stock or to landfill. In relation to material recycling and energy recovery, the study also looked at whether this occurred within the region or outside in order to identify opportunities for new business in the region.

\subsection{Data collection and limitations}

Case material flows for this article are phosphorous, plastics, textiles, waste wood and ash. Apart from phosphorous, all of these are partly recycled as material. However, a significant proportion of plastics, textiles and waste wood is used for energy production at a gasification power plant that generates electricity and district heat from solid recovered fuel (SRF). Since the beginning of 2016, landfill disposal of organic waste in Finland has been restricted by a Government Decree (Finnish Government, 2013). In combination with an increasing emphasis on $\mathrm{CE}$, this has stimulated interest in finding new solutions for material recycling; for example, ash is mainly reused in earthworks.

The available data on material flows include both primary data from companies, official statistics and environmental permits and secondary data from sources such as the research literature and national statistics. It is notable that the available information from environmental permits and related official digital services relates only to larger-scale industries requiring permits. Table 1 shows the main categories of data used for modelling and the main constraints on data availability.

Table 1: Key data sources for material flow analysis

\begin{tabular}{|l|l|l|l|}
\hline MATERIAL FLOW & Primary data & Secondary data & No data available \\
\hline Phosphorus & $\begin{array}{l}\text { Biogas plant operations and } \\
\text { digestate quality } \\
\text { Fertilizer amounts in the }\end{array}$ & $\begin{array}{l}\text { P flows in agricultural systems } \\
\text { P and N content of woody mass } \\
\text { flows }\end{array}$ & $\begin{array}{l}\text { Biowaste imports } \\
\text { Ash use in forest fertilizing }\end{array}$ \\
\hline
\end{tabular}




\begin{tabular}{|l|l|l|l|}
\hline & $\begin{array}{l}\text { region } \\
\text { Agricultural production Wood } \\
\text { production and use } \\
\text { Wood production and use }\end{array}$ & Wood use at saw mills & \\
\hline Plastics & $\begin{array}{l}\text { Official digital service VAHTI, } \\
\text { environmental permits, } \\
\text { information from plastics } \\
\text { industry companies }\end{array}$ & $\begin{array}{l}\text { Finnish national statistics, Arvi } \\
\text { project results, studies on the } \\
\text { composition of Municipal Solid } \\
\text { Waste (M SW) and Solid Recycled } \\
\text { Fuel (SRF) }\end{array}$ & $\begin{array}{l}\text { Companies that are not subject } \\
\text { to environmental permits } \\
\text { and/or have not delivered } \\
\text { information }\end{array}$ \\
\hline Textiles & $\begin{array}{l}\text { TEXIÄTE project (Dahlbo et al. } \\
\text { 2017) }\end{array}$ & $\begin{array}{l}\text { Reuse of textiles by/between } \\
\text { consumers }\end{array}$ \\
\hline Waste wood & $\begin{array}{l}\text { Official digital service VAHTI, } \\
\text { wood production and use, } \\
\text { waste wood from main } \\
\text { industries }\end{array}$ & Wood use at saw mills & $\begin{array}{l}\text { Companies that are not subject } \\
\text { to environmental permits } \\
\text { and/or have not delivered } \\
\text { information }\end{array}$ \\
\hline Ash & $\begin{array}{l}\text { Official digital service VAHTI, } \\
\text { environmental permits and } \\
\text { decisions, Finnish Food Safety } \\
\text { Authority (EVIRA) }\end{array}$ & & \\
\hline
\end{tabular}

During the data collection process, it became clear that it is challenging to find regional-level information on material flows. Data were collected from different sources and were in some cases contradictory. For some material flows, only national-level data were available. Waste management practices in the Päijät-Häme region differ from most other regions in Finland SRF because SRF is collected separately; this means that although the recycling rate for municipal waste is high, a lot of materials end up being incinerated. These special characteristics of Päijät-Häme mean that national figures do not necessarily reflect the real situation.

In addition to the challenges mentioned above, there was a lack of data in relation to the disposal and storage of materials. For instance, households store significant volumes of unused textiles and plastics, but the extent of these stocks is not known (Eskelinen et al., 2018). This is also the case for plastics that are not registered for material or energy recovery; some have been stored, some have probably ended up in nature and some would have gone to landfill prior to the ban. Table 2 shows the relevant volumes of material flows in the following categories: material flow inputs to the region $\left(m_{i n}\right)$, production in the region $\left(m_{p}\right)$, material utilisation in the region $\left(m_{c}\right)$, energy use in the region $\left(m_{e}\right)$, material utilisation outside the region $\left(m_{\text {out }}, c\right)$, energy use outside the region $\left(m_{\text {out }}, e\right)$, disposal in stocks or storage $\left(m_{d}\right)$ and deposit to landfill $\left(m_{1}\right)$.

Table 2: M aterial flow circulation, storage and deposit to landfills at Päijät-Häme region (tonnes).

\begin{tabular}{|l|l|l|l|l|l|l|l|l|}
\hline $\begin{array}{l}\text { Resource } \\
\text { category }\end{array}$ & $\begin{array}{l}\text { Inputs } \\
\text { to the } \\
\text { region } \\
\mathrm{m}_{\mathrm{in}}[\mathrm{t}]\end{array}$ & $\begin{array}{l}\text { Productio } \\
\mathrm{n} \text { in the } \\
\text { region } \\
\left.\mathrm{m}_{\mathrm{p}} \mathrm{t}\right]\end{array}$ & $\begin{array}{l}\text { Circulate } \\
\mathrm{d} \text { to } \\
\text { material } \\
\text { use in the } \\
\text { region } \\
\left.\mathrm{m}_{\mathrm{c}} \mathrm{t}\right]\end{array}$ & $\begin{array}{l}\text { Circulate } \\
\mathrm{d} \text { to } \\
\text { energy } \\
\text { use in the } \\
\text { region } \\
\mathrm{m}_{\mathrm{e}}[\mathrm{t}]\end{array}$ & $\begin{array}{l}\text { Circulate } \\
\mathrm{d} \text { to } \\
\text { material } \\
\text { use } \\
\text { outside } \\
\text { the } \\
\text { region } \\
\mathrm{m}_{\text {out },}[\mathrm{t}]\end{array}$ & $\begin{array}{l}\text { Circulate } \\
\mathrm{d} \text { to } \\
\text { energy } \\
\text { use } \\
\text { outside } \\
\text { the } \\
\text { region } \\
\mathrm{m}_{\text {out },},[\mathrm{t}]\end{array}$ & $\begin{array}{l}\text { Disposa } \\
\text { I in } \\
\text { stocks/ } \\
\text { storage } \\
\mathrm{m}_{\mathrm{d}}[\mathrm{t}]\end{array}$ & $\begin{array}{l}\text { Deposi } \\
\mathrm{t} \text { to } \\
\text { landfill } \\
\mathrm{m}_{\mathrm{l}}[\mathrm{t}]\end{array}$ \\
\hline $\begin{array}{l}\text { Phosphorou } \\
\mathrm{s}\end{array}$ & 0 & 271 & 180 & 0 & 0 & 0 & 91 & 0 \\
\hline Plastics & 3,800 & 39,300 & 170 & 20,300 & 4,840 & 13,900 & $\mathrm{NA}$ & $\mathrm{NA}$ \\
\hline
\end{tabular}




\begin{tabular}{|l|l|l|l|l|l|l|l|l|}
\hline Textiles & 1,632 & 2,672 & 127 & 2,378 & 308 & 2,235 & 166 & NA \\
\hline Waste wood & $\begin{array}{l}138,60 \\
0\end{array}$ & 371,200 & 88,500 & 400,100 & 8,200 & 17,400 & NA & 0 \\
\hline Ash & 0 & 75,200 & 23,300 & 0 & 0 & 0 & 7,900 & 49,500 \\
\hline
\end{tabular}

\subsection{Characteristics of Material Flows in Päijät-Häme and Finland}

Phosphorous is used intensively in agriculture as a fertilizer and the study of phosphorus flows focuses on nutrients and biomasses. Because phosphorus is usually a limiting nutrient in Finnish crop production, it was selected as an example of the biological aspect of CE. Efforts to close P loops have attracted increasing interest in recent years. At present, most waste flows that contain nutrients are collected at a local biogas plant in Päijät-Häme. The digestate moisture content is 33\%, with $1.8 \% \mathrm{P}$ in digestate dry matter. However, as mixing wastewater treatment plant sludge with other biowaste flows has raised concerns about pathogens, it is very likely that current digestate use cannot continue as business as usual. In wood-related cycles, phosphorus ends up as ash in sawmills and for energy production. Ash can also be used to fertilize forests. The main challenge related to open phosphorous cycles is eutrophication in water systems. Low price of mineral phosphorous makes it challenging to improve circular economy of phosphorous.

The amount of plastic waste in Finland continues to increase significantly, and the greater part of this is packaging, which is the most commonly recycled form of plastic (accounting for $32 \%$ of total plastic packaging waste in 2010). This is followed by plastics in construction waste (23\%) and agricultural plastics (20\%). M ost of the recycled plastic is low-density polyethylene (PE-LD) (Järvinen 2016). It is noteworthy that different studies report very different figures for plastic waste in Finland, making it challenging to develop an overall picture at national and especially regional level.

Päijät-Häme is of national significance in the plastics industry, with about $7 \%$ of Finnish plastics companies located in the region. Along with metals, plastics are the region's main engineering material (Eerola 2014, 53.) Material flow data for plastics were collected from relevant companies, environmental permits, waste statistics and national studies, using the ratio of national population figures to Päijät-Häme to translate national data into regional. The data were mainly from 2013 to 2015 , before the landfill ban on organic waste came into force. Producer responsibility for plastic packaging came into force in 2016 , and separate collection of post-consumer plastic packaging also commenced in that year. Since then, material and energy utilization have increased and landfilling has decreased.

A significant proportion of pre-consumer plastic waste from side flows and production can be recycled and used as raw material in the same manufacturing process (or another). Industries using thermoplastics can recycle up to $90 \%$ of their waste internally; this is not taken into account here because no reliable statistics are available. Municipal solid waste (MSW) is the main waste stream containing plastics, which account for about 13\% of M SW. (Salmenperä et al. 2015). In 2014, about half of M SW was utilized as energy, and about $17 \%$ ended up going to landfill nationally. About half of the plastic waste that ends up in landfill is post-consumer while about a quarter is pre-consumer waste. M ost of the plastics in M SW are packaging-related. (Järvinen 2016).

Although plastics have a heating value similar to oil, interest in CE and environmental values driven by national and EU regulations have shifted the emphasis to new material recycling solutions. According to Plastics Europe (2017), 22\% of plastic waste was recycled in Europe in 2017, of which 
$73 \%$ was utilized as energy while $5 \%$ still went to landfill. As compared to earlier studies, producer responsibility and the landfill ban seem in particular to have increased waste utilization for energy production.

Textile waste is currently collected in Finland either as a component of M SW or as part of SRF (as in the Päijät-Häme region). The amount of textile material in MSW is growing as a result of fastchanging fashion and the poor quality of garments produced. Consumer behaviour increases the environmental impacts of textile production in terms of water, energy and chemical consumption in the production chain. However, only about $20 \%$ of discarded textiles are collected by charity organizations and other NGOs. The ideal solution would be to encourage consumers to purchase durable and recyclable garments only when needed and repairing, reusing or recycling the textile as material until it can no longer be reused. (Dahlbo et al., 2017)

In practice, there is no sign of a decrease in consumption of clothes, as shown by the increasing percentage of textiles in M SW. As no primary regional data are available for textile waste in the Päijät-Häme region, the flow data were derived from a quantitative national study of textile waste (Dahlbo et al., 2017). The ratio of Finland's population to that of Päijät-Häme in 2013 was used to estimate amounts of regional textile waste, based on textile waste data from 2012. As the landfill ban on organic waste was not in force at that time, it was assumed that the amount of textile waste in M SW was 5.8\% (based on the Finnish Solid Waste Association's statistics from 2016 (JLY). In the absence of the landfill ban on organic waste, the item 'disposal to landfills' in Table 2 was deemed not applicable.

The national landfill ban on organic waste has prompted research and surveys addressing the simultaneous development of a chain of waste collection, sorting, identification, separation and recovery (Telaketju, 2017). The European Union's Waste Directive update (European Parliament, 2018) sets a separate collection requirement for textile waste by 2025 , further accelerating the need for national and regional data regarding textile waste qualities, quantities, logistics chains and so on.

Waste wood is generated mainly by the forestry industry and by the construction and demolition sectors. The EU Waste Framework Directive targets 70\% recycling of non-hazardous construction and demolition waste $(C D \& W)$ by 2020 . While there are currently no reliable national statistics on CD\&W recycling, the Finnish M inistry of the Environment (2015) estimates that $26 \%$ of CD\&W is recycled as material. According to Dahlbo et al. (2015), 36\% of Finnish CD\&W is typically wood, which is used mainly for energy recovery. M aterial recycling of CD\&W waste wood is challenging, as it contains nails, remnants of concrete, paints and other contaminants. In the Päijät-Häme region, information on wood material flows was based on wood use and waste statistics.

In Finland, approximately 1.5 million tonnes of ashes are generated annually. Ashes generated at combustion plants and boilers are considered valuable as raw materials; these residues are likely to be high in nutrients such as $\mathrm{Ca}, \mathrm{K}, \mathrm{P}$ and $\mathrm{Mg}$, and their reported high $\mathrm{pH}$ and neutralising capacity supports their use as a fertilizer (Augusto et al., 2008). Additionally, these residues have proven geotechnical properties, and their use in earth constructions is widely reported (M anskinen, 2013). To promote the reuse of ashes, Finland has introduced some national regulations-for example, the Finnish Waste Tax Act specified a tax per tonne of landfilled ash, which increased to 70 euros per tonne at the beginning of 2016 (Waste Tax Act, 2010).

Although ashes are widely reused in Finland, Finnish environmental legislation designates these 
residues as waste. For that reason, institutional or professional utilisation of such waste always requires an official permit, decision or registration by the relevant authorities. For the purposes of this research, data for ashes generated in the region of Päijät-Häme were sourced from environmental permits (Environmental Protection Act, 2000), decisions under the decree for the utilisation of waste in earth constructions Decree, 2009; Decree, 2012), Finnish Food Safety Authority (Evira) registrations and the Finnish official digital reporting service VAHTI.

\subsection{Material Flow Indicators}

Figure 1 presents a breakdown of waste materials for the case region, with flows assigned to the following categories: material inputs to the region, material outputs from the region, production in the region, deposit and disposal in the region, circulation for material use and circulation for energy use. Indicators describing circular economy efficiency in a region were developed on the basis of these factors.

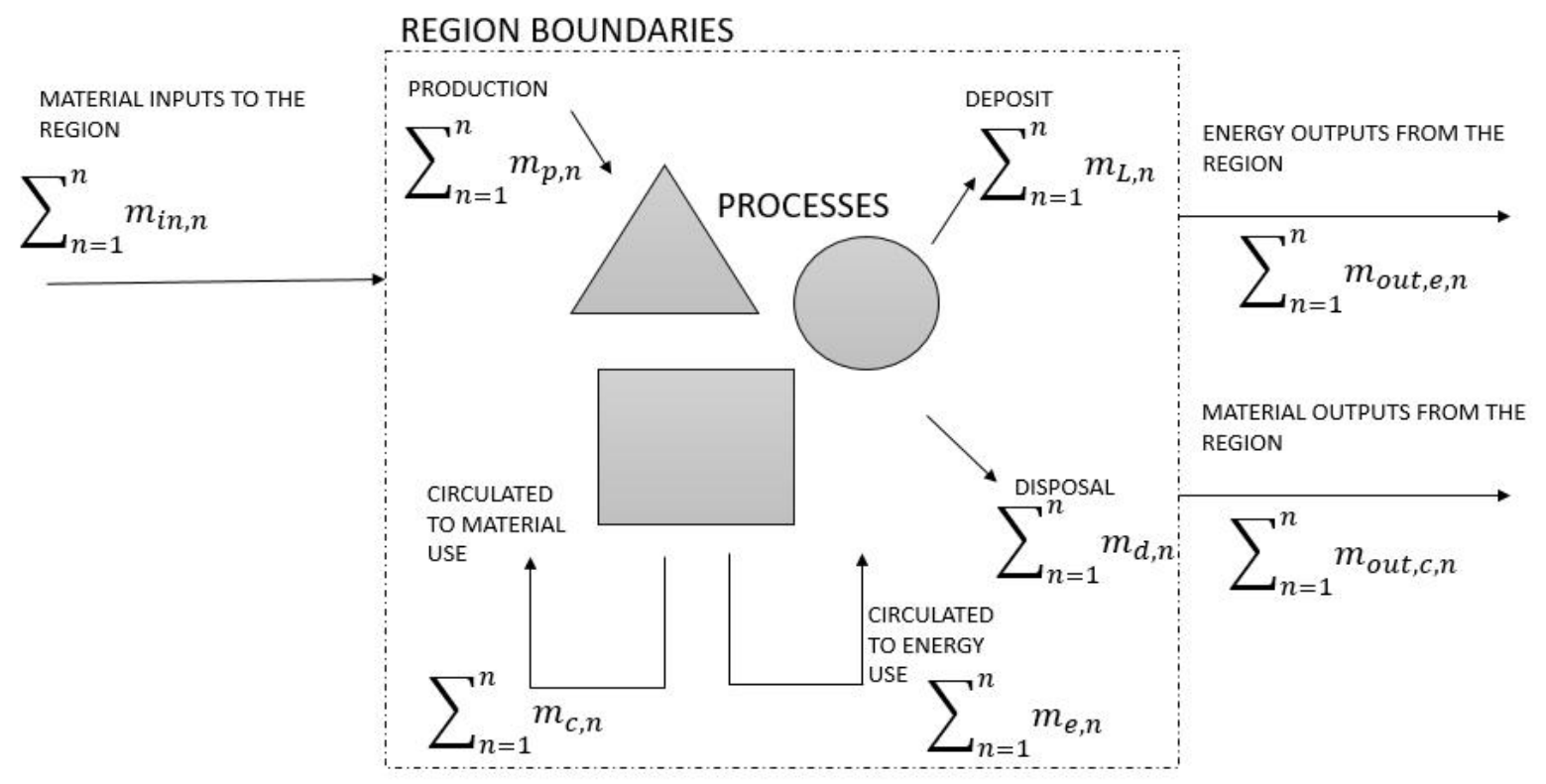

Figure 1. Material flows: material inputs to the region $\left(m_{i n}\right)$, production in the region $\left(m_{p}\right)$, material recycling in the region $\left(m_{c}\right)$, energy use in the region $\left(m_{e}\right)$, deposit to landfill $\left(m_{1}\right)$, disposal in stocks $\left(m_{d}\right)$, energy use outside the region $\left(m_{\text {out }}, e\right)$ and material recycling outside the region $\left(m_{\text {out }}, c\right)$,.

The factors created to evaluate regional circular economy for a given waste material are based on output-input ratios $(R)$ of masses. The first indicator $\left(R_{c e}\right)$ specifies how much material is circulated to material use or to energy use as compared to total material input and production in the region, describing how well that material flow is utilized as material or energy. This indicator $\left(R_{c e}\right)$ describes the overall material flow circulation ratio of the total amount of materials i.e. the materials produced in the region and transported there.

$$
R_{c e}=\frac{\sum_{n=1}^{n} m_{c, n}+\sum_{n=1}^{n} m_{o u t, c, n}+\sum_{n=1}^{n} m_{e, n}+\sum_{n=1}^{n} m_{\text {out }, e, n}}{\sum_{n=1}^{n} m_{\text {in }, n}+\sum_{n=1}^{n} m_{p, n}}
$$

The second indicator $\left(R_{c, \text { eff }}\right)$ specifies how much material is circulated to material use as compared to total material and energy circulation. The higher the value of the indicator, the more efficient is 
material use in terms of the waste hierarchy for that material. This indicator ( $\left.R_{c, \text { eff }}\right)$ describes the overall material recycling rate versus to energy use.

$$
R_{c, e f f}=\frac{\sum_{n=1}^{n} m_{c, n}+\sum_{n=1}^{n} m_{\text {out }, c, n}}{\sum_{n=1}^{n} m_{c, n}+\sum_{n=1}^{n} m_{\text {out }, c, n}+\sum_{n=1}^{n} m_{e, n}+\sum_{n=1}^{n} m_{\text {out }, e, n}}
$$

The third indicator ( $\left.R_{\text {region}}\right)$ specifies the share of circulation in the region as compared to total circulation, capturing the importance of a material flow within the regional context. This indicator $\left(R_{\text {region }}\right)$ describes the overall ratio of material circulation inside the region in order to evaluate the situation in the regional level. This may provide useful data from the regional development perspective.

$$
R_{\text {region }}=\frac{\sum_{n=1}^{n} m_{c, n}+\sum_{n=1}^{n} m_{e, n}}{\sum_{n=1}^{n} m_{c, n}+\sum_{n=1}^{n} m_{\text {out }, c, n}+\sum_{n=1}^{n} m_{e, n}+\sum_{n=1}^{n} m_{\text {out }, e, n}}
$$

These indicators improve understanding of differences between various material flows, enabling methods of improving regional CE to be developed.

\section{RESULTS AND DISCUSSION}

The regional material flow indicator results for phosphorus, plastics, textiles, waste wood and ash, i.e. material circulation to material or energy use $\left(R_{c e}\right)$, material circulation to material use $\left(R_{c e}\right.$ eff $)$ and material circulation in the region ( $\left.R_{\text {Region }}\right)$, are presented in the Table 3.

Table 3. Regional indicators for Päijät-Häme

\begin{tabular}{|l|l|l|l|}
\hline Resource category & $\begin{array}{l}\text { Material circulation to } \\
\text { material or energy use } \\
\left(\mathrm{R}_{\mathrm{ce}}\right)\end{array}$ & $\begin{array}{l}\text { Material circulation to } \\
\text { material use }\left(\mathrm{R}_{\mathrm{ce}, \text { eff }}\right)\end{array}$ & $\begin{array}{l}\text { Material circulation in } \\
\text { the region }\left(\mathrm{R}_{\text {Region }}\right)\end{array}$ \\
\hline Phosphorous & 0.66 & 1.00 & 1.00 \\
\hline Plastics & 0.91 & 0.13 & 0.52 \\
\hline Textiles & 1.17 & 0.09 & 0.50 \\
\hline Waste wood & 1.01 & 0.19 & 0.95 \\
\hline Ash & 0.31 & 1.00 & 1.00 \\
\hline
\end{tabular}

The results show that the $R_{c e}$ indicator is highest for textiles (1.17) and for waste wood (1.01); the $R_{c e}$ indicator for plastics is also high (0.91). This confirms that these waste materials are circulated to material use or utilised for energy production. However, it is notable that Rc,eff is low for all of these waste residues (plastics 0.13 , textiles 0.09 and waste wood 0.19 ), suggesting that these waste materials are recovered effectively but are used mainly for energy recovery. The results align with Finnish national waste statistics showing that utilisation of municipal waste has increased in recent years but mainly because of increasing energy recovery (Statistics Finland, 2019). Based on these findings, circulation of these materials does not conform to European waste hierarchy principles. 
Although Finnish national and regional CE targets emphasize material re-use rather than energy recovery, the present findings suggests that energy recovery is favoured in practice. This owes partly to the absence of material re-use options in many regions, especially for textiles and waste wood, and a pre-feasibility study for the first large-scale textile recycling plant was recently initiated (Yle, 2018). Ecosystems, facilities and novel technologies are also needed to promote recycling of waste woods and plastics. In response to stricter EU recycling requirements, more treatment capacity for plastic wastes will be implemented in southern Finland (Talouselämä, 2018).

It is notable that the $\mathrm{R}_{\mathrm{ce}}$ indicator is above 1.0 for textiles and waste wood. This reflects the challenges of data collection and the lack of primary data, such as statistical information on textile waste at either regional or national level. For present purposes, the volume of textile waste was estimated in terms of the quantity of textiles in municipal waste as well as national figures (Dahlbo et al., 2017). Re-use of textiles was calculated on the basis of national estimates.

As shown in Table 3, the highest values for circulation to material use ( $\left.R_{c e, e f f}\right)$ are for ash (1.0) and phosphorus (1.0), partly because these materials cannot be used for energy production. In addition, the $\mathrm{R}_{\text {region }}$ indicator is $\mathbf{1 . 0}$ for both of these wastes, indicating that they are used in the region. This is unsurprising, as transporting these over a distance would not be profitable. According to the Finnish waste tax provision (2010) that a tax of 70 euros must be paid per tonne of landfilled ash, it would not be economically viable for transportation costs to exceed landfill costs, and the ashes are therefore re-used within a range of approximately $100 \mathrm{~km}$. Accordingly, biogas plant digestate containing nutrients that include phosphorus is returned along with compost phosphorus for agricultural use within a radius of approximately $50 \mathrm{~km}$. Digestate currently has no economic value.

Some phosphorus may be transported as digestate outside the region, but we have no detailed information in that regard. The use of phosphorus related to wood combustion ash remains unclear, but it is assumed that most of it is currently disposed of in landfills or other non-fertilizer uses. As there is no energy use for phosphorus, all circulation is to material use. In addition, it can be assumed that all $P$ is likely to be circulated inside the region. There is little information about $P$ in biowaste imported to the local biogas plant, but this amount is likely to be marginal when compared to biogas plant feedstock production in the region.

The results also show that the $\mathrm{R}_{\text {region }}$ indicator value for material circulation of waste wood within the region is high (1.00), which suggests that all wood waste is circulated within the region as compared to only half of plastics (0.52) and textiles (0.50). The case study also confirms that the Rregion indicator correlates with the price of materials. For example, the price of plastic waste is highly variable, depending on the type and quality of plastic, but on average, it is close to zero. The same applies to textiles, which means that it is not profitable in most cases to transport materials over longer distances.

\section{CONCLUSIONS}

While the idea of the circular economy is gaining in importance at regional, national and international levels, the few existing measures of circularity focus mainly on the product level. The aim of the present research was to create and test regional level indicators, but this proved difficult because of a lack of reliable data. The original aim was to develop an input-output study of different 
material flows, but the available data were insufficient. Primary data on material flows were found in statistics and environmental permits, but these focus mainly on waste flows rather than on materials used for production. Additionally, as small-scale production does not necessarily require an environmental permit, not all waste flows or sidestreams are reported.

The present study highlights the difficulty of sourcing exact regional or even national information on volumes of waste fractions. It also shows that current statistics for areas such as construction and demolition waste are not available, even though the EU has set a $70 \%$ recycling target for that sector. As some of the figures for plastic and textile waste are estimates based on national and regional research rather than primary data, these are in some cases contradictory. That said, the main aim here was to test and develop indicators, and the indicator results should be treated as examples. By highlighting its limitations in this way, current reporting can be enhanced to advance circular economy goals and monitoring.

This research also confirms the complexity of circular economy ecosystems and the challenges of closing the loops. In the case region of Päijät-Häme, many companies are small, and material flows consist of various industrial sidestreams. In practice, SM Es lack the resources to promote reuse of sidestreams, especially where essential actors are missing from the value chain-for example, the region still has no recycling facilities for textiles. Moreover, this research confirms that ashes originating from small power plants are not utilised, and the transition to a circular economy requires utilisation of all flows. While data collection for this research was challenging, the indicators developed here help to simplify the complexity of material flows and provide a basis for evaluating regional circularity. Although it was originally hoped to evaluate material circulation for the whole value chain (i.e. from material use in manufacturing to reuse and recycling), the indicators effectively capture the circulation of waste materials.

\section{Acknowledgements}

The regional material flow analysis presented in this paper was a part of Kiertoliike project funded by the European Regional Development Fund.

\section{REFERENCES}

Augusto, L., Bakker M R., M eredieu C., 2008. Wood ash applications to temperate forest ecosystemspotential benefits and drawbacks. Plant Soil 306:181-198. DOI 10.1007/s11104-008-9570-z

Bringezu, S., Schütz, H., Saurat, M., M oll, S., Acosta-Fernández, J., Steger, S. 2009. Europe's Resource Use. Basic Trends, Global and Sectoral Patterns and Environmental and Socioeconomic Impacts. Sustainable Resource M anagement. pp. 52-154.

Dahlbo, H., Bacher, J., Lahtinen, K., Jouttijärvi, T., Suoheimo, P., M attila, T., Sironen, S., M yllymaa, T., Saramäki, K. 2015. Construction and demolition waste management - a holistic evaluation of environmental performance. Journal of Cleaner Production, 107. pp 333-341. Available at: http://dx.doi.org/10.1016/i.jclepro.2015.02.073 [Accessed January 2019]

Dahlbo, H., Aalto, K.; Eskelinen, H.; Salmenperä, H. 2017. Increasing textile circulation Consequences and requirements. Sustainable Production and Consumption, 9. pp. 44-57. Available 
at: https:// doi-org.ezproxy.cc.lut.fi/10.1016/j.spc.2016.06.005 [Accessed December 2018]

Decree, 2009. The Government Decree 403/2009 concerning the recovery of certain wastes in earth construction, Valtioneuvoston asetus 403/2009 eräiden jätteiden hyödyntämisestä maarakentamisessa annetun valtioneuvoston asetuksen liitteiden muuttamisesta, (in Finnish). Available at: http:// finlex.fi. [Accessed January 2019]

Decree, 2012. Decree on the operations concerning fertilizer products and their supervision, $\mathrm{M}$ aa- ja metsätalousministeriön asetus lannoitevalmisteita koskevan toiminnan harjoittamisesta ja sen valvonnasta. Asetus nro 11/12, (in Finnish). Available at: http:// www.finlex.fi. [Accessed January 2019]

Dittrich, M., Giljum, S., Lutter, S., Polzin, C. 2012. Green Economies around the World? Implications of Re-source Use for Development and the Environment. International Journal of Sustainability in Higher Education. Vol. 14 Issue: 1. Available at: https://doiorg.ezproxy.cc.lut.fi/10.1108/ijshe.2013.24914aaa.004 [Accessed January 2019]

Di M aio, F., Rem, P.C., Balde, K., Polder, M. 2017. M easuring resource efficiency and circular economy: A market value approach. Resource, Conservation and Recycling, 122, pp. 163-171. Available at: https:// doi-org.ezproxy.cc.lut.fi/10.1016/j.resconrec.2017.02.009 [Accessed M ay 2019]

Eerola, S. 2014. University-Industry Co-operation Using a Practice-based Innovation Tool: Case advisory Professorship Programme in M aterials Technology. Doctoral thesis. Tampere University of technology. Tampere.

Ellen M acArthur Foundation. 2015. What is a circular economy? Available at: https:// www.ellenmacarthurfoundation.org/circular-economy. [Accessed January 2019]

Environmental Protection Act. 2000. Environmental Act 86/2000. Ympäristönsuojelulaki 86/2000 (in Finnish). Available at: http://www.finlex.fi. [Accessed January 2019]

Eskelinen, H., Teerihalme, H., Lamberg, V., Hämäläinen T., Sahimaa, O., Ranta V., Alijoki, T., Eteläaho P. and Hilli, M . Uudelleenkäyttö ja sen edistäminen. 2018. Suomen Ympäristökeskuksen raportteja 18/2018. Available at: https://helda.helsinki.fi/bitstream/handle/10138/236338/SYKEra_19_2018.pdf? sequence=1 [Accessed January 2019]

European Commission. 2008. Directive 2008/98/EC of the European Parliament and of the Council of 19 November 2008 on Waste and Repealing Certain Directives. Available at: http://eurlex.europa.eu/legal-content/EN/TXT/PDF/?uri=CELEX:32008L0098\&from=EN [Accessed January 2019]

European Parliament. 2018. Recital 42 of the amended Directive 2008/98/EC. Available at: http:// www.europarl.europa.eu/sides/getDoc.do?type=TA\& reference=P8-TA-20180114\&format=XM L\&language=EN [Accessed January 2019]

Finnish Government. 2013. Government decree on landfills 331/2013. Available at: http:// www.finlex.fi/en/laki/kaannokset/2013/en20130331.pdf [Accessed January 2019] 
Franklin-Johnson, E., Figge, F., Canning, L. 2016. Resource duration as a managerial indicator for Circular Economy performance. Journal of Cleaner Production. Available at: http://dx.doi.org/10.1016/j.jclepro.2016.05.023 [Accessed J une 2019]

Haas, W., Krausmann, F., Wiedenhofer., Heinz, M. 2016. How Circular Is the Global Economy? A Sociometabolic Analysis. In Haberl, H., Fischer-Kowalski M., Krausmann F., Winwarter, V. (Eds.) Social Ecology: Society-Nature Relations across Time and Space. Springer, pp. 259-275.

Huysman, S., De Schaepmeester, J., Ragaert, K., Dewulf, J., De M eester, S. 2017. Performance indicator for a circular economy: A case study on post-industrial plastic waste. Resources, Conservation and Recycling. 120, pp. 46-54. Available at: https:// doiorg.ezproxy.cc.lut.fi/10.1016/i.resconrec.2017.01.013 [Accessed June 2019]

JLY (Finnish Solid Waste Association). 2016. Databank for waste composition (in Finnish). [Accessed January 2019]

Järvinen, P. 2016. Muovien kierrätys ja hyötykäyttö Suomessa (in Finnish). Porvoo: M uovifakta.

Kirchherr, J., Reike, D., Hekkert, M. 2017. Conceptualizing the circular economy: An analysis of 114 definitions. Resources, Conservation and Recycling. 127, pp. 221-232. Available at:

http://dx.doi.org/10.1016/j.resconrec.2017.09.005

Korhonen J., Honkasalo A., Seppälä J. 2018. Circular Economy: The Concept and its Limitations. Ecological Economics. 143, pp. 37-46. Available at: http://dx.doi.org/10.1016/j.ecolecon.2017.06.041

Lahtinen P. 2001. Fly ash mixtures as flexible structural materials for low-volume roads. Finnra reports, 70. ISBN 951-726-826-2, TIEH 3200716E. Edita Oyj. Helsinki.

Lettenmeier, M., Liedtke, C., Rohn, H. 2014. Eight tons of material footprint - Suggestion for a resource cap for household consumption in Finland. Resources, 3 (3), pp. 488-515.

Manskinen, K., 2013. Utilisation aspects of ashes and green liquor dregs, Doctoral Dissertation, Aalto university, Espoo, Finland.

Ministry of Environment. 2015. Utilisation of construction and demolition waste: Rakennus- ja purkujätteiden hyödyntäminen (in Finnish). Presentation at Puujätteet kierrätykseen -conference 27.5.2015. Available at: http://www.ym.fi/fi-

Fl/Ajankohtaista/Tapahtuma Puujatteet kierratykseen_semin(33145) [Accessed June 2018]

Plastics Europe. 2017. Plastics - the Facts 2017: An analysis of European plastics production, demand and waste data. Available at:

https://www. plasticseurope.org/application/files/5715/1717/4180/Plastics the facts 2017 FINAL for website one page.pdf [Accessed January 2019]

Regional Council of Päijät-Häme. 2017. Päijät-Hämeen maakuntastrategia 2018-2021. Available at: 
http://www.paijat-hame.fi/wp-content/uploads/2017/08/M aakuntastrategia_2018_2021.pdf [Accessed November 2018]

Rockström, J. et al. 2009. A safe operating space for humanity. Nature 461, pp. 472-475. Available at: 10.1038/461472a [Accessed November 2018]

Salmenperä H., M oliis K. \& Nevala S-M . 2015. Jätemäärien ennakointi vuoteen 2030. The M inistry of Environment report 17/2015 (in Finnish). Available at: http://hdl.handle.net/10138/155189 [Accessed February 2019]

ScoreLCA. 2015. Circular Economy: Concepts and evaluation methods. SCORE LCA study n. 2014-02.

Smol, M., Kulczycka, J. \& Avdiushchenko, A. 2017. Circular economy indicators in relation to ecoinnovation in European regions. Clean Technologies and Environmental Policy 19 (3): 669-678. Available at: https:// doi.org/10.1007/s10098-016-1323-8 [Accessed February 2019]

Statistics Finland. 2019. Yhdyskuntajätteiden määrä ei ole kasvanut paljoakaan ja hyödyntäminen on korvannut kaatopaikkasijoittamisen (in Finnish). Available at:

https://www.stat.fi/til/jate/2017/13/jate 201713 2019-01-09 tie 001 fi.html. [Accessed January 2019]

Steffen, W., Richardson, K., Rockström, J., Cornell, S.E. Fetzer, I. et al. 2015. Planetary boundaries: Guiding human development on a changing planet. Science.

Talouselämä. 2018. Fortum kolminkertaistaa uusiomuovin käsittelykapasiteettinsa - "Suomen ratkaisuille maailmanlaajuista kysyntää" (in Finnish). https:// www.talouselama.fi/uutiset/fortumkolminkertaistaa-uusiomuovin-kasittelykapasiteettinsa-suomen-ratkaisuille-maailmanlaajuistakysyntaa/81780735-2edf-32c3-b5fc-fb22c31d01ef [Accessed January 2019]

Telaketju. 2017. Available at: www.telaketju.fi/en [Accessed December 2018]

Waste Tax Act (2010) Jäteverolaki 17.12.2010/1126 (in Finnish). Available at: http://finlex.fi. [Accessed May 2018]

Witjes, S., Lozano, R. 2016. Towards a more Circular Economy: Proposing a framework linking sustainable public procurement and sustainable business models. Resources, Conservation and Recycling, 112, pp. 37-44. Available at: https://doi.org/10.1016/j.resconrec.2016.04.015 [Accessed February 2019]

Yle. 2018. Suomeen on perusteilla laitos, joka käsittelisi koko maan poistotekstiilit uusiokäyttöön (in Finnish). Available at: https://yle.fi/uutiset/3-10286252 [Accessed January 2019] 